\title{
Travel Demand Prediction during COVID-19 Pandemic: Educational and Working Trips at the University of Padova
}

\author{
Riccardo Ceccato $^{1}$ (D), Riccardo Rossi ${ }^{1, *(D)}$ and Massimiliano Gastaldi ${ }^{1,2}$ (D) \\ 1 Department of Civil, Architectural and Environmental Engineering, University of Padova, Via Marzolo, 9, \\ 35131 Padova, Italy; riccardo.ceccato@dicea.unipd.it (R.C.); massimiliano.gastaldi@unipd.it (M.G.) \\ 2 Department of General Psychology, University of Padova, Via Venezia, 8, 35131 Padova, Italy \\ * Correspondence: riccardo.rossi@unipd.it
}

Citation: Ceccato, R.; Rossi, R.; Gastaldi, M. Travel Demand Prediction during COVID-19 Pandemic: Educational and Working Trips at the University of Padova. Sustainability 2021, 13, 6596. https:// doi.org/10.3390/su13126596

Academic Editors: Armando Cartenì and Ilaria Henke

Received: 13 May 2021

Accepted: 5 June 2021

Published: 9 June 2021

Publisher's Note: MDPI stays neutral with regard to jurisdictional claims in published maps and institutional affiliations.

Copyright: (c) 2021 by the authors. Licensee MDPI, Basel, Switzerland. This article is an open access article distributed under the terms and conditions of the Creative Commons Attribution (CC BY) license (https:// creativecommons.org/licenses/by/ $4.0 /)$.

\begin{abstract}
The diffusion of the COVID-19 pandemic has induced fundamental changes in travel habits. Although many previous authors have analysed factors affecting observed variations in travel demand, only a few works have focused on predictions of future new normal conditions when people will be allowed to decide whether to travel or not, although risk mitigation measures will still be enforced on vehicles, and innovative mobility services will be implemented. In addition, few authors have considered future mandatory trips of students that constitute a great part of everyday travels and are fundamental for the development of society. In this paper, logistic regression models were calibrated by using data from a revealed and stated-preferences mobility survey administered to students and employees at the University of Padova (Italy), to predict variables impacting on their decisions to perform educational and working trips in the new normal phase. Results highlighted that these factors are different between students and employees; furthermore, available travel alternatives and specific risk mitigation measures on vehicles were found to be significant. Moreover, the promotion of the use of bikes, as well as bike sharing, car pooling and micro mobility among students can effectively foster sustainable mobility habits. On the other hand, countermeasures on studying/working places resulted in a slight effect on travel decisions.
\end{abstract}

Keywords: COVID-19; sustainable mobility; trip cancellation; travel demand; public transport; micro mobility

\section{Introduction}

In the last year, the sudden diffusion of SARS-CoV-2 led to deep changes in everyday life worldwide [1]. The virus generates an infectious disease called COVID-19, with the first confirmed case recorded in China in December 2019 [2]. After that, the virus rapidly spread all over the world, becoming a global pandemic [3]. Many countries experienced severe loss of lives [4]. At the end of March 2020, the World Health Organization reported about 750,900 confirmed cases and 36,400 deaths in the world [5], whereas, one year later, these numbers grew up to about 126,372,400 confirmed cases and 2,769,700 deaths [6]. In the same periods, in Europe, there were about 423,900 confirmed cases and 26,700 deaths in 2020 [5], and 44,191,600 confirmed cases and 954,800 deaths in 2021 [6].

Consequently, in order to contain the spread of SARS-CoV-2, many governments implemented severe countermeasures [7]. These non-pharmaceutical interventions were country-specific [7-9], however, they globally aimed at limiting interpersonal interactions to reduce human-to-human transmission of the virus [10-12]. These measures included social distancing, quarantine for infected people, local lockdowns allowing only essential travel, closures of universities and schools, restrictions on commercial and recreational activities (e.g., non-essential stores, restaurants, theatres), remote working and online learning $[1,8,9,12-15]$. In Italy, different response measures were enforced, depending on the trend of total registered infected cases; in particular, after the first death in this country on 23 February 2020, the Italian government locally applied strict interventions to reduce 
the spread of the virus [16], which were gradually expanded to the whole territory. From March 9th to May 3rd, public spaces, educational institutions and non-essential shops were closed, non-essential travel was prohibited, as well as trips outside the municipality of residence, mass gatherings were not allowed and the capacity of public transport was drastically limited or the service was suspended [17]. After this national lockdown, the number of COVID-19 cases declined, therefore some measures were relaxed, allowing many commercial activities to open and citizens to freely travel while respecting social distancing and using facemasks [8]. Then, due to increasing infections, different strict restrictions were enforced depending on the diffusion of the virus in each region, including the closure of non-essential activities, online learning, remote working, travel restrictions and public transport capacity limitations [18].

Countermeasures against the diffusion of COVID-19 had a significant impact on mobility $[1,12,13,19]$ because of direct limitations or bans on transport services, forbidden trips, the closure of activities, as well as self-imposed individual restrictions [20]. Many authors reported significant changes in users' travel habits worldwide $[7,8,21,22]$, with variations in the frequency of trips, travel purposes and modal split [12], which may have varied in accordance with country-specific factors $[23,24]$ and socio-economic characteristics of citizens [25]. As regards European nations, comparing trip statistics before and after the pandemic: in Germany, about $60 \%$ of persons changed transport mode [14], in particular, the number of people performing monomodal trips rose from $68 \%$ to $83 \%$ [26]; in Greece, the average number of daily trips decreased by $50 \%$ [12]; in the Netherlands, about $80 \%$ of people reduced their out-of-home activities and the number of trips decreased by $55 \%$ compared to 2019 [9]; in Poland, 50\% of people reduced their travel time by more than two thirds [20]; commuting trips dropped by $80 \%$ in Spain [13]; in Italy, the number of people reporting no daily trips increased by $27 \%$ [24] and the number of internal trips decreased by $50 \%[27,28]$, while commuting trips were reduced by $69 \%$ [8]; even in Sweden, where restrictions were voluntary, $86 \%$ of the population changed their commuting trips with $66 \%$ of people who commuted for 5 days a week prior to the pandemic deciding not to travel [29]. In particular, public transport, despite its fundamental role in everyday mobility needs, was the most affected travel mode $[8,30]$ since it was often perceived as a high-risk environment for contagion [31]. In many countries, a shift from public transport to car and active modes was reported [7]; comparing the pre-COVID-19 period with the pandemic period, in Germany, the number of young adults using public transport dropped from $47 \%$ to $19 \%$ [26]; in Norway, the number of people stating to never use buses increased by $19 \%$ [24]; in Sweden, the modal share of public transport for commuting trips was reduced from $45 \%$ to $10 \%$ [8]. In Italy, the High Institute for Transport Education and Research (ISFORT) estimated that [28], in 2019, 25\% of trips were performed by active modes, $63 \%$ by private motorized means and $12 \%$ by public transport means; whereas, during the lockdown, the corresponding values became $35 \%, 61 \%$ and $4 \%$, respectively; lastly, after the relaxation of restrictions, $31 \%$ of trips by active modes, $61 \%$ by private motorized means and $8 \%$ on public transport modes were reported.

Because of these severe changes in the everyday mobility of individuals, nonnegative effects on the urban environment were observed worldwide. First, significant reductions of pollutants produced by vehicles, in particular $\mathrm{NO}_{2}$ and $\mathrm{CO}$, were recorded in many countries [32] such as Brazil [33], China [34], France [35], Spain [36], Italy [37,38] and the United States [34]. Moreover, road accidents decreased in many cities [39], thereby lowering the number of fatalities [40]. Furthermore, several countries experienced improved liveability on streets due to a lowering of congestion [1,41], traffic delay [42] and noise pollution [43]. These analyses point out the importance of the transport sector in the sustainable development of cities [39] and highlight the need to understand the factors affecting changes in mobility habits during the COVID-19 pandemic.

To reach this aim, many authors applied different methods [7]. Abdullah et al. [21] implemented a multinomial logistic regression to study mode choice for primary trips by using data from different countries in the world. Moslem et al. [11] adopted a Best-Worst 
Method to examine mobility choices in Italy before and during the COVID-19 pandemic. Pawar et al. [44] calibrated a decision tree to evaluate the decisions of commuters about travel modes in India; later, Pawar et al. [23] used the same dataset to develop a multinomial logit model to study travel frequency for both work and non-work purposes. Borkowsi et al. [20] applied a generalized linear model to analyse travel time variations in Poland. Fatmi et al. [45] used ordered and binary logit models to investigate changes in indoor and outdoor activities, as well as long-distance travels, in Canada. Irawan et al. [46] developed a structural equation model to analyse variations in activity and travel behaviour after the COVID-19 outbreak in Indonesia. Politis et al. [12,25] applied a generalized linear model and ordinary-least squares regressions to predict trip frequency and duration in Greece. Scorrano and Danielis [17] modelled mode choice before and during the COVID-19 pandemic using revealed-preferences and stated-preferences data from an Italian city.

Nevertheless, besides the analysis about past changes due to the COVID-19 outbreak, the prediction of future travel habits in "new normal" conditions, when strict measures are relaxed and citizens can decide whether to perform a trip or not and are having to live with the virus $[13,23]$, is fundamental for future transport system planning and policymaking $[4,9]$. Indeed, many variations in the travel behaviour of users are likely to be maintained in the future $[4,14,26,47]$, thus defining a significantly different travel demand with respect to the pre-pandemic period $[12,19,30]$. Following this perspective, travel demand prediction is important, since, as previously described, a new greener mobility can effectively foster the sustainable development of cities [37]. In order to reach this aim, both the United Nations [48] and European Commission [49] have stressed the need to address and maintain sustainable travel habits that emerged during the COVID-19 pandemic.

Specifically, long-lasting changes might be prompted by the following factors. Firstly, remote working and online learning may induce the cancellation of many systematic trips $[4,8,9,46,50]$ since individuals have the possibility to carry out the corresponding activities at home $[7,29,51]$. Although factors influencing both remote working and the prediction of its adoption were investigated by many authors $[7,10,13,29,51,52]$, only a few previous works focused on the impact of online learning and students' behaviours on travel demand, but without any predictive analysis. Due to the COVID-19 pandemic, students experienced drastic changes in their lives [15]. Travel restrictions as well as the closure of schools and universities led to severe impacts on their mobility habits $[9,53,54]$, which are likely to be maintained in the future [55]. Overall, significant variations in the use of transport systems during the pandemic were caused by the cancellation of trips previously performed by students since they constituted a great part of their mandatory trips in normal (pre-pandemic) periods $[4,9,56,57]$, thus significantly affecting regional and urban traffic [58]. Furthermore, the travel behaviour of students is different from that of the general population [59], pointing out the need for a specific analysis [58]. For these reasons, the prediction of their travel decisions is fundamental to manage transport services and provide efficient and safe trips, in particular for educational purposes, covering a crucial role for the future of students and society [60]. Specifically, Aristovnik et al. [15] studied the effects of COVID-19 on students' lives including trip cancellation, using data from several countries in the world; nevertheless, they did not predict potential future trips. Analogously, de Haas et al. [9] investigated the experience of home education and trip reduction in the Netherlands, but only in the current pandemic context. Similarly, Nguyen et al. [61] evaluated factors impacting on the perceptions and behaviours of students in Vietnam, but without any demand forecasting. Lastly, Wu et al. [62] analysed the mobility habits of students in China; however, they referred only to international travel.

Secondly, safety measures on transport means may affect users' perceptions of the health risk of travelling $[1,13]$, thereby significantly modifying mobility behaviours, in particular towards public transport modes [7,16,31]. Thirdly, new attitudes towards active modes and a new range of mobility services (e.g., micro mobility) should be considered when predicting travel demand since they can produce significant variations in future modal share $[7,11,14,16,24]$. 
To the best of the authors' knowledge, no previous works have jointly considered all these factors to predict travel demand in "new normal" periods, when people can decide whether to perform a trip or not. In particular, Bhaduri et al. [63] developed a multiple discrete choice extreme value model to jointly predict mode choice and trip frequency in India; however, they did not evaluate the effect of health risk mitigation measures on travel means. Campisi et al. [16] predicted shifts towards walking and cycling in an Italian region, without explicitly considering safety measures on travel means. Irawan et al. [64] modelled future intentions to carry out outdoor activities in Indonesian cities under "new normal" conditions, but they did not include potential mobility alternatives in their analysis. Even if they did not refer to future post-pandemic periods, Parady et al. [65] investigated the frequency of leisure and shopping activities in Japan when self-restrictions were applied, but without directly considering travel modes. On the other hand, Awad-Núñez et al. [13] estimated the willingness to accept and pay for measures to improve safety conditions on public transport and shared modes in Spain, but they implicitly assumed that users decided to travel. Bin et al. [8] used data from different countries to calibrate binary regressions forecasting the likelihood of travel habits observed during the pandemic period being maintained; however, they did not consider travel options and safety measures. Hensher et al. [51] predicted the number of remote working days and weekly commuting trips in Australia when restrictions are relaxed, but without including health risk mitigation measures on travel means.

The aim of this paper is to analyse factors affecting the choice not to perform a systematic trip in "new normal" conditions for workers and students, when people can decide whether to travel or not, but when measures to mitigate the risk of SARS-CoV-2 diffusion on transport means are still enforced and new mobility services are available. To reach this target, unlike previous works, specific stated-preferences experiments about mode choice and travel decisions were designed and administered to employees and students of the University of Padova (Italy) between July and September 2020; the obtained data were used to calibrate binary logistic regressions predicting potential travel demand, by explicitly considering individuals' socio-economic characteristics, risk perceptions, attitudes towards online working and education and mode choices conditioned to safety measures on travel means and new mobility services. Furthermore, results of the analysis were compared between the two groups of individuals in order to identify potential differences in variables affecting travel intentions.

Stated-preferences surveys are widely adopted in transport planning analysis and they have both advantages and drawbacks if compared with a revealed-preferences approach. [66]. For example, the former allow the researcher to have more control on choice situations [66], with potential benefits for the subsequent calibration of predictive models [67]. In addition, many tasks with alternative scenarios that might not be experienced by individuals can be tested [67]. However, respondents often tend to cast their actual behaviour in a better light, leading to self-selection bias [66]. Moreover, answering fatigue grows with the complexity of experiments [68]. In addition, interviewees might not be familiar with the proposed alternatives, leading to unreliable answers [69]. In this paper, stated-preferences surveys were designed and used since the main aim was to predict travel demand in future alternative scenarios, which could not be directly observed at the time of the survey administration. In order to overcome some of the previously described drawbacks of this approach, realistic scenarios were generated [67]; in particular, the unit of analysis of choice tasks was a real performed trip with alternative travel modes having realistic trip attributes that were derived from existing transport services in similar areas.

The present work aims to provide the following contributions. Firstly, unlike many previous works focusing only on systematic trips carried out by employees, this paper sheds light on trips performed by students in future conditions, which constitute a nonnegligible part of daily travels. In addition, it contributes to the analysis of factors affecting travel demand with mandatory purposes in the "new normal" phase, by using outcomes from people who had previously experienced remote working and online learning for 
several months, thus increasing the reliability of results; indeed, the majority of previous authors adopted data about people who did not carry out these online activities for long periods, potentially leading to biased results [52]. Furthermore, students and employees can actually choose whether to travel or not [46]. Moreover, in this paper, safety measures and new travel modes, which are likely to be adopted in the future, are explicitly and jointly considered for the first time, thereby predicting travel demand under the most probable future realistic conditions.

For these reasons, results will be helpful for both academics and decision makers. The former can benefit from the analysis and prediction of potential long-term changes in travel habits of students and workers because of the pandemic emergency. Factors affecting future travel demand can support the latter to address resources to create a resilient transport system, which can accommodate the fundamental mobility needs of people ensuring proper health safety during the phase of coexistence with the virus (SARSCoV-2). Furthermore, local authorities will be provided with a sound and concrete basis to promote sustainable travel habits, thus contributing to the maintenance of the few non-negative effects of the COVID-19 pandemic on transport systems and society that occurred in many cities worldwide, such as reduction of congestion, road accidents and environmental pollution.

\section{Materials and Methods}

\subsection{Mobility Survey}

In order to analyse travel demand related to mandatory activities during a "new normal" period, data from a mobility survey administered to employees and students in the University of Padova (Italy) were used. These specific groups were selected since they contain individuals who can decide whether to take a trip or not, because of remote working and online learning, thereby considering realistic conditions of the modelled period $[7,8,29]$. In addition, answers were collected from July to September 2020, when people had accumulated experience of these online activities for four months [52].

In particular, the survey consisted of four sections; questions in each part were properly tailored to be addressed to workers or students:

1. A brief introduction was shown and questions about travel habits of respondents before the outbreak of COVID-19 (February 2020) were posed. Specifically, interviewees were asked to report their usage frequency of several travel modes and trip frequency for different travel purposes. Moreover, detailed information about a typical working/educational trip was collected: origin and destination, travel mode(s), trip characteristics (length, duration, walk and wait time), cost of parking or transit pass, as well as satisfaction level of the adopted means. After that, the same questions about trip frequency were posed referring to the lockdown (March and April 2020) and post-lockdown (May and June 2020) periods. In addition, the frequency of remote working/online education and attitudes towards these activities was investigated.

2. In this section, questions to analyse the relationship between respondents and the COVID-19 pandemic were posed. Specifically, interviewees were asked to rate the risk of travelling on several transport means; furthermore, the level of their concern about the current pandemic was measured, and their opinions about the future potential diffusion of SARS-CoV-2 and about potential risk-mitigation measures in working/studying environments were collected.

3. Stated-preferences experiments were administered to investigate mode choice of respondents, considering different measures on travel means to mitigate the spread of the virus. In particular, individuals were asked to focus on a future scenario in which they could freely decide whether to travel towards their work/school place or not; it is worth mentioning that this hypothesis was actually announced by the Italian Government and corresponding proper regulations for the new academic year were already defined by the University of Padova at the time of survey administration. The unit of analysis of stated-preferences experiments was the working/educational 
trip reported by respondents in Section 1, assuming that the same trip could be performed in the future. Alternative modes were selected according to the length of the journey and considering both existing and innovative means, which are planned to be introduced in Padova. Specifically, if travelled distance was less than 5 kilometres, private car, urban bus/tram, bike, bike sharing, car sharing, car pooling and electricscooter sharing were considered; on the contrary, only private car, suburban bus/train and car pooling were presented. The trip attributes of each mode were costs (public transit ticket or pass, tolls, fuel), in-vehicle time, walking time to reach the public transit stop and waiting time at the stop (for public transport means), or walking time to reach the parked vehicle (for car, car sharing, bike sharing and scooter sharing). In addition, mode-specific health risk mitigation measures were included as attributes of alternatives: for instance, frequent sanitization, proper ventilation system, booking system to manage crowding, the presence of a person designated to enforce safety measures and mandatory face masks (for public transport) or frequent sanitization of means and available hand sanitizing gel (for car, bike, bike sharing and scooter sharing). Attributes of alternative modes were calculated by considering information on the reported trip and data about public transit operators, car sharing and bike sharing services (fares and subscription costs), along with the average cost of fuels. Thereby, choice tasks were based on a real trip with realistic attributes, thus increasing the realism of choices and, thus, the reliability of answers [70]. For each of the two types of stated-preferences experiments, D-optimal designs were generated, obtaining D-efficiency values above 0.9 [67]. In particular, 5 levels for cost and time attributes were considered, adopting 20\%-step variations from the base level and 4 levels for safety measures. In this way, a design with 60 questions was generated, which were divided into 15 blocks for short trips, and a design with 24 questions divided into 8 blocks for long trips. Consequently, each respondent had to face 4 choice tasks, if she had performed a short trip, or 6 choice tasks if she had carried out a long trip. Each block was randomly assigned to each individual. The entire procedure was performed using R statistical software [71]. Furthermore, after each experiment, respondents were asked to state whether they preferred to travel using the previously selected mode or stay at home adopting remote working/online learning. In this way, the decision to perform a systematic trip or not was explicitly related to mode choice considering "new normal" travel conditions.

4. In the last section, socio-economic questions at household (e.g., number of cars, income) and individual (e.g., age) level were posed.

The survey was administered online by sending a web-link to 64,987 students and 5680 employees through official e-mail addresses. The numbers of complete questionnaires were 5385 and 1213 for students and workers, respectively; the two sample sizes were appropriate for a margin of error of $10 \%$ at $95 \%$ confidence level [67].

\subsection{Travel Demand Analysis and Prediction}

To predict future travel demand and analyse factors affecting the choice to cancel a systematic trip, confirmatory answers after each stated-preferences task in Section 3 were considered. Since the outcomes of these questions were binary (to travel or to stay at home), binary logistic regressions were implemented [72,73] for both students and employees. Each of the two models predicted the willingness not to travel, thus adopting online education for students, and remote working for employees. Variables included in the model specification phase are reported in Table 1 and they refer to individual, household and trip level. In particular, variables related to travel mode chosen in the stated-preferences experiments were included in the set, thereby explicitly considering potential changes in mobility habits in the "new normal" phase. Furthermore, risk-mitigation measures both on travel means and working/studying places, which are likely to be applied in the future, were added, in order to evaluate their effect on travel decision. 
Table 1. Exogenous variables used in the binary logistic regression models.

\begin{tabular}{|c|c|c|c|}
\hline Name & Description & Type & Level \\
\hline AGE & Age & Metric & Individual \\
\hline COMM & Commuter student & Dummy & Individual \\
\hline F_BIKE & Frequency of use of bike [times/week] & Metric & Individual \\
\hline F_BSHAR & Frequency of use of bike sharing [times/week] & Metric & Individual \\
\hline F_BUS_S & Frequency of use of suburban bus [times/week] & Metric & Individual \\
\hline F_BUS_U & Frequency of use of urban bus/tram [times/week] & Metric & Individual \\
\hline F_CAR_DR & Frequency of use of car as a driver [times/week] & Metric & Individual \\
\hline F_CAR_PASS & Frequency of use of car with passengers [times/week] & Metric & Individual \\
\hline F_CSHAR & Frequency of use of car sharing [times/week] & Metric & Individual \\
\hline F_MOTO & Frequency of use of motorbike [times/week] & Metric & Individual \\
\hline F_PASS & Frequency of use of car as a passenger [times/week] & Metric & Individual \\
\hline F_TAXI & Frequency of use of taxi [times/week] & Metric & Individual \\
\hline F_TRAIN & Frequency of use of train [times/week] & Metric & Individual \\
\hline F_WALK & Frequency of walking [times/week] & Metric & Individual \\
\hline FREQ & Past trip frequency [times/week] & Metric & Trip \\
\hline FUT_COV & $\begin{array}{l}\text { Opinion on level of future potential diffusion of } \\
\text { SARS-CoV-2 [5-point scale, ranging from "Very little } \\
\text { diffused" to "Very diffused", with the specific answer: } \\
\text { "No longer present"] }\end{array}$ & Categorical & Individual \\
\hline GENDER_M & Male & Dummy & Individual \\
\hline HH_BIKE & Number of bikes & Metric & Household \\
\hline HH_CAR & Number of cars & Metric & Household \\
\hline HH_LIC & Number of driving licensed people & Metric & Household \\
\hline HH_MEMB & Number of members & Metric & Household \\
\hline HH_UND & Number of underaged children & Metric & Household \\
\hline INCOME & Income $[1000 €]$ & Metric & Household \\
\hline LIC & Driving license & Dummy & Individual \\
\hline MEAS_A & $\begin{array}{l}\text { Limited number of available seats in working/studying } \\
\text { places in university buildings [5-point scale, ranging } \\
\text { from "Not at all important" to "Very important"] }\end{array}$ & Categorical & Individual \\
\hline MEAS_B & $\begin{array}{l}\text { Mandatory face mask usage in working/studying } \\
\text { places in university buildings [5-point scale, ranging } \\
\text { from "Not at all important" to "Very important"] }\end{array}$ & Categorical & Individual \\
\hline MEAS_C & $\begin{array}{l}\text { Mandatory glove usage in working/studying places in } \\
\text { university buildings [5-point scale, ranging from "Not at } \\
\text { all important" to "Very important"] }\end{array}$ & Categorical & Individual \\
\hline MEAS_D & $\begin{array}{c}\text { Free hand sanitizing gel at entries (and face masks, for } \\
\text { employees) in university buildings [5-point scale, } \\
\text { ranging from "Not at all important" to "Very } \\
\text { important"] }\end{array}$ & Categorical & Individual \\
\hline MEAS_E & $\begin{array}{l}\text { Body heat check at entries in university buildings } \\
\text { [5-point scale, ranging from "Not at all important" to } \\
\text { "Very important"] }\end{array}$ & Categorical & Individual \\
\hline
\end{tabular}


Table 1. Cont.

\begin{tabular}{|c|c|c|c|}
\hline Name & Description & Type & Level \\
\hline MEAS_F & $\begin{array}{c}\text { Effective supervision of risk-mitigation measures } \\
\text { enforcement in university buildings [5-point scale, } \\
\text { ranging from "Not at all important" to "Very } \\
\text { important"] }\end{array}$ & Categorical & Individual \\
\hline MEAS_G & $\begin{array}{l}\text { Daily sanitization of places in university buildings } \\
\text { [5-point scale, ranging from "Not at all important" to } \\
\text { "Very important"] }\end{array}$ & Categorical & Individual \\
\hline MEAS_H & $\begin{array}{l}\text { Sanitization of classroom after each lesson (for students) } \\
\text { in university buildings [5-point scale, ranging from } \\
\text { "Not at all important" to "Very important"] }\end{array}$ & Categorical & Individual \\
\hline P_BIKE & Used bike in the past for this trip & Dummy & Trip \\
\hline P_BSHAR & Used bike sharing in the past for this trip & Dummy & Trip \\
\hline P_BUS_S & Used suburban bus in the past for this trip & Dummy & Trip \\
\hline P_BUS_U & Used urban bus in the past for this trip & Dummy & Trip \\
\hline P_CAR_DR & Used car as a driver in the past for this trip & Dummy & Trip \\
\hline P_CAR_PASS & Used car with passengers in the past for this trip & Dummy & Trip \\
\hline P_CSHAR & Used car sharing in the past for this trip & Dummy & Trip \\
\hline P_MOTO & Used motorbike in the past for this trip & Dummy & Trip \\
\hline P_MULTIM & Used more than one travel mode in the past for this trip & Dummy & Trip \\
\hline P_PASS & Used car as a passenger in the past for this trip & Dummy & Trip \\
\hline P_TAXI & Used taxi in the past for this trip & Dummy & Trip \\
\hline P_TRAIN & Used train in the past for this trip & Dummy & Trip \\
\hline P_WALK & Walked in the past for this trip & Dummy & Trip \\
\hline PERC_COV & $\begin{array}{l}\text { Level of concern about the current pandemic [5-point } \\
\text { scale, ranging from "Very worried" to "Very relaxed"] }\end{array}$ & Categorical & Individual \\
\hline PROP_ONA & $\begin{array}{c}\text { Level of attitude towards remote working/online } \\
\text { learning [5-point scale, ranging from “Very unwilling" } \\
\text { to "Very willing"] }\end{array}$ & Categorical & Individual \\
\hline Q_CAR & $\begin{array}{l}\text { Quality level of road infrastructure [5-point scale, } \\
\text { ranging from "Very poor" to "Very good"] }\end{array}$ & Categorical & Individual \\
\hline Q_CIRC & $\begin{array}{l}\text { Quality level of traffic circulation [5-point scale, ranging } \\
\text { from "Very poor" to "Very good"] }\end{array}$ & Categorical & Individual \\
\hline Q_PT & $\begin{array}{l}\text { Quality level of public transport services [5-point scale, } \\
\text { ranging from "Very poor" to "Very good"] }\end{array}$ & Categorical & Individual \\
\hline Q_WALK & $\begin{array}{l}\text { Quality level of walking path [5-point scale, ranging } \\
\text { from "Very poor" to "Very good"] }\end{array}$ & Categorical & Individual \\
\hline RISK & Individual COVID-19 health risk & Dummy & Individual \\
\hline $\mathrm{SAF}_{-}^{*}$ & $\begin{array}{l}\text { Perceived level of travelling health risk on transport } \\
\text { means }\left(^{*}\right)[5 \text {-point scale, ranging from "Very unsafe" to } \\
\text { "Very safe"] }\end{array}$ & Categorical & Individual \\
\hline SAT & $\begin{array}{l}\text { Satisfaction level for the adopted means [5-point scale, } \\
\text { ranging from "I am very dissatisfied" to "I am very } \\
\text { satisfied"] }\end{array}$ & Categorical & Individual \\
\hline SP_BP_A & Selected bike with no measures (ref. private car) & Dummy & Trip \\
\hline
\end{tabular}


Table 1. Cont.

\begin{tabular}{|c|c|c|c|}
\hline Name & Description & Type & Level \\
\hline SP_BP_B & $\begin{array}{l}\text { Selected bike with safety paths ensuring physical } \\
\text { distance (ref. private car) }\end{array}$ & Dummy & Trip \\
\hline SP_BP_C & $\begin{array}{l}\text { Selected bike with hand sanitizing gel at bike racks (ref. } \\
\text { private car) }\end{array}$ & Dummy & Trip \\
\hline SP_BP_D & $\begin{array}{l}\text { Selected bike with mandatory face mask usage (ref. } \\
\text { private car) }\end{array}$ & Dummy & Trip \\
\hline SP_BS_A & Selected bike sharing with no measures (ref. private car) & Dummy & Trip \\
\hline SP_BS_B & $\begin{array}{l}\text { Selected bike sharing with frequent sanitization of } \\
\text { means by operators (ref. private car) }\end{array}$ & Dummy & Trip \\
\hline SP_BS_C & $\begin{array}{l}\text { Selected bike sharing with hand sanitizing gel and } \\
\text { gloves on each bike (ref. private car) }\end{array}$ & Dummy & Trip \\
\hline SP_BS_D & $\begin{array}{l}\text { Selected bike sharing with safety paths ensuring } \\
\text { physical distance (ref. private car) }\end{array}$ & Dummy & Trip \\
\hline SP_COST & Cost for the selected mode from SP experiments & Metric & Trip \\
\hline SP_CP_A & Selected car pooling with no measures (ref. private car) & Dummy & Trip \\
\hline SP_CP_B & $\begin{array}{l}\text { Selected car pooling with mandatory face mask usage } \\
\text { (ref. private car) }\end{array}$ & Dummy & Trip \\
\hline SP_CP_C & $\begin{array}{c}\text { Selected car pooling with hand sanitizing gel on each } \\
\text { vehicle (ref. private car) }\end{array}$ & Dummy & Trip \\
\hline SP_CP_D & $\begin{array}{l}\text { Selected car pooling with mandatory physical distance } \\
\text { (ref. private car) }\end{array}$ & Dummy & Trip \\
\hline SP_IVT & $\begin{array}{l}\text { In-vehicle travel time for the selected mode from SP } \\
\text { experiments }\end{array}$ & Metric & Trip \\
\hline SP_MO_A & $\begin{array}{l}\text { Selected scooter sharing with no measures (ref. private } \\
\text { car) }\end{array}$ & Dummy & Trip \\
\hline SP_MO_B & $\begin{array}{l}\text { Selected scooter sharing with frequent sanitization of } \\
\text { means by operators (ref. private car) }\end{array}$ & Dummy & Trip \\
\hline SP_MO_C & $\begin{array}{l}\text { Selected scooter sharing with hand sanitizing gel on } \\
\text { each vehicle (ref. private car) }\end{array}$ & Dummy & Trip \\
\hline SP_MO_D & $\begin{array}{l}\text { Selected scooter sharing with safety paths ensuring } \\
\text { physical distance (ref. private car) }\end{array}$ & Dummy & Trip \\
\hline SP_PT_A & $\begin{array}{l}\text { Selected public transport with no measures (ref. private } \\
\qquad \text { car) }\end{array}$ & Dummy & Trip \\
\hline SP_PT_B & $\begin{array}{l}\text { Selected public transport with frequent sanitization by } \\
\text { operator and proper ventilation system (ref. private car) }\end{array}$ & Dummy & Trip \\
\hline SP_PT_C & $\begin{array}{l}\text { Selected public transport with a booking system to } \\
\text { manage crowding (ref. private car) }\end{array}$ & Dummy & Trip \\
\hline SP_PT_D & $\begin{array}{c}\text { Selected public transport with mandatory face mask } \\
\text { usage and the presence of a person designated to } \\
\text { enforce safety measures (ref. private car) }\end{array}$ & Dummy & Trip \\
\hline SP_WAIT & $\begin{array}{l}\text { Waiting travel time for the selected mode from SP } \\
\text { experiments }\end{array}$ & Metric & Trip \\
\hline SP_WALK & $\begin{array}{l}\text { Walking travel time for the selected mode from SP } \\
\text { experiments }\end{array}$ & Metric & Trip \\
\hline SUB_BUS_S & Suburban bus pass & Dummy & Individual \\
\hline SUB_BUS_U & Urban bus/tram pass & Dummy & Individual \\
\hline SUB_TRAIN & Train pass & Dummy & Individual \\
\hline
\end{tabular}


In addition, factor analysis was applied in order to identify potential patterns among variables related to the perceived level of COVID-19 contagion risk on considered travel means, and to understand if they can be summarized in a smaller set of factors [74]. All analyses were performed using R statistical software [75].

\section{Results}

\subsection{Sample Characteristics}

Table 2 reports the main socio-economic characteristics and travel habits of interviewed students (columns 2 and 3) and employees (columns 4 and 5). Observing this table, one can note that students and employees showed a similar usage of active modes ( $29 \%$ and $30 \%$, respectively) before the COVID-19 outbreak. Moreover, for both samples, the modal share of bike use ( $14 \%$ for the first group and $22 \%$ for the second group) was greater than the typical value in Italy (about 3\%) [76]. On the other hand, workers reported a higher percentage of commuting trips carried out by private car $(37 \%)$ than students $(8 \%)$. In addition, much fewer public transport trips were recorded for the former $(30 \%)$ than the latter $(61 \%)$, indeed, the number of students who owned a public transport pass was about twice the corresponding value for employees.

Table 2. Demographic characteristics and travel habits of sampled students and employees.

\begin{tabular}{|c|c|c|c|c|}
\hline & \multicolumn{2}{|c|}{ Students } & \multicolumn{2}{|c|}{ Employees } \\
\hline & $\mathbf{N}$ & $\%$ & $\mathbf{N}$ & $\%$ \\
\hline Totals & 5385 & & 1213 & \\
\hline \multicolumn{5}{|l|}{ Household members } \\
\hline 1 & 140 & 3 & 201 & 17 \\
\hline 2 & 535 & 10 & 347 & 29 \\
\hline 3 & 1433 & 27 & 283 & 23 \\
\hline 4 & 2174 & 40 & 294 & 24 \\
\hline More than 4 & 140 & 3 & 201 & 17 \\
\hline \multicolumn{5}{|l|}{ Licensed drivers } \\
\hline 0 & 0 & 0 & 7 & 0 \\
\hline 1 & 1449 & 27 & 319 & 26 \\
\hline 2 & 731 & 14 & 675 & 56 \\
\hline 3 & 1842 & 34 & 128 & 11 \\
\hline More than 3 & 1363 & 25 & 84 & 7 \\
\hline \multicolumn{5}{|l|}{ Household cars } \\
\hline 0 & 848 & 16 & 55 & 5 \\
\hline 1 & 1127 & 21 & 476 & 39 \\
\hline 2 & 2034 & 38 & 581 & 48 \\
\hline 3 & 1140 & 21 & 90 & 7 \\
\hline More than 3 & 236 & 4 & 11 & 1 \\
\hline \multicolumn{5}{|l|}{ Household bikes } \\
\hline 0 & 560 & 10 & 100 & 9 \\
\hline 1 & 1354 & 25 & 186 & 15 \\
\hline 2 & 853 & 16 & 323 & 27 \\
\hline 3 & 985 & 18 & 259 & 21 \\
\hline More than 3 & 1633 & 30 & 345 & 28 \\
\hline \multicolumn{5}{|c|}{ Household income [€/month] } \\
\hline Less than 1000 & 1243 & 23 & 10 & 1 \\
\hline $1000-1500$ & 782 & 15 & 206 & 17 \\
\hline 1500-2000 & 905 & 17 & 133 & 11 \\
\hline $2000-3000$ & 1256 & 23 & 395 & 33 \\
\hline $3000-4000$ & 697 & 13 & 255 & 21 \\
\hline $4000-6000$ & 307 & 6 & 164 & 13 \\
\hline $6000-10,000$ & 108 & 2 & 35 & 3 \\
\hline More than 10,000 & 87 & 2 & 15 & 1 \\
\hline
\end{tabular}


Table 2. Cont.

\begin{tabular}{|c|c|c|c|c|}
\hline & \multicolumn{2}{|c|}{ Students } & \multicolumn{2}{|c|}{ Employees } \\
\hline & $\mathbf{N}$ & $\%$ & $\mathbf{N}$ & $\%$ \\
\hline \multicolumn{5}{|l|}{ Gender } \\
\hline Female & 3366 & 63 & 668 & 55 \\
\hline Male & 2019 & 37 & 545 & 45 \\
\hline \multicolumn{5}{|l|}{ Age } \\
\hline $18-20$ & 1721 & 32 & 3 & 0 \\
\hline $21-24$ & 2878 & 53 & 4 & 0 \\
\hline $25-29$ & 583 & 11 & 56 & 5 \\
\hline $30-34$ & 127 & 2 & 119 & 10 \\
\hline $35-44$ & 76 & 1 & 332 & 27 \\
\hline $45-54$ & 0 & 0 & 396 & 33 \\
\hline 55-64 & 0 & 0 & 266 & 22 \\
\hline More than 65 & 0 & 0 & 37 & 3 \\
\hline \multicolumn{5}{|l|}{ Bus pass } \\
\hline Yes & 726 & 13 & 65 & 5 \\
\hline No & 4659 & 87 & 1148 & 95 \\
\hline \multicolumn{5}{|l|}{ Train pass } \\
\hline Yes & 2040 & 38 & 193 & 16 \\
\hline No & 3345 & 62 & 1020 & 84 \\
\hline \multicolumn{5}{|c|}{ Modal share before COVID-19 } \\
\hline Bike & 759 & 14 & 264 & 22 \\
\hline Bike sharing & 12 & 0 & 1 & 0 \\
\hline Car pooling & 3 & 0 & 0 & 0 \\
\hline Motorbike & 72 & 1 & 38 & 3 \\
\hline Private car & 456 & 8 & 453 & 37 \\
\hline Scooter & 3 & 0 & 0 & 0 \\
\hline Sub urban bus & 765 & 14 & 66 & 6 \\
\hline Train & 2191 & 41 & 203 & 17 \\
\hline Urban bus & 339 & 6 & 87 & 7 \\
\hline Walking & 785 & 15 & 98 & 8 \\
\hline
\end{tabular}

\subsection{Factor Analysis}

Potential correlation patterns among variables related to the perceived risk level of travelling on the 14 considered transport means were investigated by applying factor analysis [17]. In particular, this technique was implemented for the two sampled groups. In order to test the appropriateness of factor analysis, partial correlation matrix, Bartlett's test of sphericity and the Measure of Sampling Adequacy were estimated. In both cases, matrices showed several cell values above 0.70, Bartlett's tests were significant ( $p$-value $<0.001$, for students, and $p$-value $<0.001$, for employees) and MSAs were above 0.8 (Kaiser-MeyerOlkin measure: 0.83 and 0.81 ), thus indicating that the selected technique could produce representative factors [74]. The number of factors was defined by adopting scree test criterion, factor loadings were calculated by applying varimax rotation and the consistency of the scale was evaluated by using Cronbach's alpha. Table 3 reports factor loadings, for which a cut-off value of 0.4 was considered [74] and variance explained by each factor, for the two samples. 
Table 3. Results of Factor Analysis on perceived risk level of travelling with different travel modes for the two samples.

\begin{tabular}{|c|c|c|c|c|c|c|c|c|}
\hline \multirow{2}{*}{$\begin{array}{c}\text { Travel Modes: } \\
\text { Perceived Risk Level }\end{array}$} & \multicolumn{4}{|c|}{ Students } & \multicolumn{4}{|c|}{ Employees } \\
\hline & Factor1 & Factor2 & Factor3 & Factor4 & Factor1 & Factor2 & Factor3 & Factor4 \\
\hline Bike & 0.86 & & & & 0.86 & & & \\
\hline Bike sharing & & & 0.49 & & 0.41 & & 0.42 & \\
\hline Car as driver & 0.50 & & & & 0.52 & & & \\
\hline Car as passenger & & & & 0.88 & & & & 0.88 \\
\hline Car pooling & & & 0.85 & & & & 0.81 & \\
\hline Car sharing & & & 0.91 & & & & 0.87 & \\
\hline Car with passengers & & & & 0.84 & & & & 0.88 \\
\hline Motorbike & 0.75 & & & & 0.79 & & & \\
\hline Scooter & 0.81 & & & & 0.80 & & & \\
\hline Sub urban bus & & 0.94 & & & & 0.95 & & \\
\hline Taxi & & & 0.58 & & & & 0.54 & \\
\hline Train & & 0.79 & & & & 0.80 & & \\
\hline Urban bus/tram & & 0.92 & & & & 0.91 & & \\
\hline Walking & 0.68 & & & & 0.63 & & & \\
\hline Variance explained & 0.20 & 0.20 & 0.17 & 0.12 & 0.21 & 0.20 & 0.15 & 0.11 \\
\hline
\end{tabular}

By observing Table 3, one can note that bike sharing shows significant factor loadings for both Factor1 and Factor3; however, the application of other rotation methods (e.g., oblimin and promax) indicated that the variable should be associated with Factor3 [74]. Moreover, for the two samples, Cronbach's alphas were greater than 0.7, suggesting good consistencies of the defined scales [74]. Furthermore, Table 3 highlights that the same patterns were obtained for both samples, thus indicating that students and employees shared similar opinions about the health risk of travelling on different transport means. Specifically, Factor1 groups individual travel modes (bike, car as driver, motorbike, electric scooter and walking), which have a null risk of contagion from COVID-19. Factor2 is associated with public transport means (sub urban bus, urban bus and train), where crowding events might cause an increasing level of diffusion of the virus, but where strict risk mitigation measures are enforced. Factor 3 includes travel modes where users share either the trip (car pooling and taxi) or the vehicle (bike sharing and car sharing), and for which no specific regulations are defined. Factor4 contains private car modes considering the presence of other passengers (car as passenger and car as driver with passenger), where a moderate risk of SARS-CoV-2 diffusion among travellers might occur. Therefore, results pointed out that correlation patterns among travel modes are related to different levels of potential contagion and enforced risk mitigation measures, suggesting that these interventions might significantly affect risk perception and, therefore, should be considered in the following analysis. For this reason, factor scores were calculated using Bartlett's method [77] and then included as independent variables in the binary logistic regression models; specifically, following the previous description, Factor1, Factor2, Factor3 and Factor4 were named SAF_INDIV, SAF_PT, SAF_SH and SAF_CPASS, respectively.

\subsection{Binary Logistic Regressions}

For each of the two studied samples, a binary logistic regression model predicting the probability of cancelling the trip and, thus, adopting online learning or remote working was calibrated. For both models, independent variables were selected by applying an automated stepwise procedure. All categorical variables were coded as dummy variables, considering the neutral point as the reference level. Furthermore, in order to assess collinearity among exogenous variables, correlation matrices were evaluated for each model; in particular, Pearson coefficients were calculated when both variables were metric, Phi coefficients for correlations between two dichotomous variables and point-biserial correlations when one variable was metric and the other dichotomous. In addition, multicollinearity was tested by estimating variance inflation factors for each variable. 
Table 4 shows estimation results for students and employees.

Table 4. Trip cancellation models for students and employees.

\begin{tabular}{|c|c|c|c|c|c|c|c|c|}
\hline \multirow[b]{2}{*}{ Name } & \multicolumn{4}{|c|}{ Students } & \multicolumn{4}{|c|}{ Employees } \\
\hline & Coeff. & SE & z-Value & $p$-Value & Coeff. & SE & z-Value & $p$-Value \\
\hline (Intercept) & 0.027 & 0.283 & 0.094 & 0.924 & 0.997 & 0.604 & 1.652 & $0.098^{+}$ \\
\hline AGE & 0.035 & 0.008 & 4.156 & $<0.001^{* * *}$ & -0.021 & 0.005 & -4.694 & $<0.001^{* * *}$ \\
\hline F_BUS_S & & & & & -0.282 & 0.066 & -4.246 & $<0.001^{* * *}$ \\
\hline F_BUS_U & -0.026 & 0.014 & -1.888 & $0.059^{\dagger}$ & & & & \\
\hline F_CAR_DR & 0.015 & 0.011 & 1.372 & 0.170 & & & & \\
\hline F_CAR_PASS & & & & & 0.079 & 0.030 & 2.567 & $0.011 *$ \\
\hline F_MÖTO & & & & & 0.166 & 0.063 & 2.640 & $0.008^{* *}$ \\
\hline F_PASS & & & & & -0.063 & 0.043 & -1.463 & 0.143 \\
\hline F_TRAIN & 0.038 & 0.012 & 3.112 & $0.002 * *$ & 0.138 & 0.028 & 4.889 & $<0.001^{* * *}$ \\
\hline F_WALK & -0.037 & 0.012 & -3.096 & $0.002 * *$ & & & & \\
\hline FREQ & -0.063 & 0.026 & -2.442 & 0.015 * & -0.133 & 0.063 & -1.920 & $0.055^{\dagger}$ \\
\hline FUT_COV_2 & -0.306 & 0.077 & -3.953 & $<0.001^{* * *}$ & -0.749 & 0.410 & -1.830 & $0.067^{+}$ \\
\hline FUT_COV_5 & 0.222 & 0.054 & 4.087 & $<0.001^{* * *}$ & 0.263 & 0.098 & 2.704 & $0.007^{* *}$ \\
\hline FUT_COV_6 & 0.601 & 0.147 & 4.080 & $<0.001^{* * *}$ & 0.437 & 0.149 & 2.919 & $0.004^{* *}$ \\
\hline GENDER_M & -0.113 & 0.048 & -2.339 & 0.019 * & & & & \\
\hline HH_BIKE & & & & & -0.121 & 0.034 & -3.577 & $<0.001^{* * *}$ \\
\hline HH_CAR/HH_LIC & & & & & 0.351 & 0.137 & 2.557 & $0.010 * *$ \\
\hline HH_MEMB & 0.027 & 0.021 & 1.324 & 0.185 & & & & \\
\hline HH_UND & & & & & 0.084 & 0.058 & 1.445 & 0.149 \\
\hline INCOME & & & & & 0.093 & 0.025 & 3.748 & $<0.001 * * *$ \\
\hline LIC & & & & & -1.118 & 0.293 & -3.815 & $<0.001^{* * *}$ \\
\hline MEAS_A_4 & 0.232 & 0.071 & 3.267 & $0.001^{* *}$ & 0.526 & 0.213 & 2.472 & $0.013 *$ \\
\hline MEAS_A_5 & 0.481 & 0.077 & 6.257 & $<0.001^{* * *}$ & 1.167 & 0.218 & 5.341 & $<0.001 * * *$ \\
\hline MEAS_B_1 & 0.249 & 0.180 & 1.378 & 0.168 & & & & \\
\hline MEAS_B_2 & 0.228 & 0.105 & 2.159 & $0.031 *$ & & & & \\
\hline MEAS_B_4 & & & & & -0.787 & 0.257 & -3.060 & $0.002 * *$ \\
\hline MEAS_B_5 & & & & & -1.342 & 0.252 & -5.330 & $<0.001 * * *$ \\
\hline MEAS_C_2 & & & & & 0.217 & 0.105 & 2.074 & 0.038 * \\
\hline MEAS_C_5 & 0.166 & 0.110 & 1.508 & 0.132 & & & & \\
\hline MEAS_D_2 & & & & & 0.784 & 0.600 & 1.306 & 0.191 \\
\hline MEAS_D_5 & -0.153 & 0.052 & -2.965 & $0.003^{* *}$ & & & & \\
\hline MEAS_E_2 & & & & & 0.474 & 0.249 & 1.899 & $0.057^{+}$ \\
\hline MEAS_E_4 & & & & & 0.535 & 0.194 & 2.753 & $0.006^{* *}$ \\
\hline MEAS_E_5 & & & & & 0.641 & 0.196 & 3.269 & $0.001^{* *}$ \\
\hline MEAS_F_5 & & & & & -0.254 & 0.113 & -2.259 & $0.024 *$ \\
\hline MEAS_G_4 & -0.081 & 0.055 & -1.481 & 0.139 & 0.160 & 0.107 & 1.499 & 0.134 \\
\hline P_BIKE & -0.121 & 0.078 & -1.554 & 0.120 & 1.040 & 0.164 & 6.335 & $<0.001^{* * *}$ \\
\hline P_BUS_S & -0.186 & 0.079 & -2.358 & $0.018^{*}$ & 1.471 & 0.414 & 3.546 & $<0.001^{* * *}$ \\
\hline P_MOTO & & & & & -0.950 & 0.408 & -2.326 & $0.020 *$ \\
\hline P_MULTIM & & & & & -0.457 & 0.110 & -4.161 & $<0.001 * * *$ \\
\hline P_PASS & & & & & 1.032 & 0.410 & 2.515 & 0.012 * \\
\hline P_WALK & & & & & 0.994 & 0.199 & 5.006 & $<0.001^{* * *}$ \\
\hline PERC_COV_4 & 0.124 & 0.053 & 2.311 & 0.021 * & & & & \\
\hline PROP_ONA_1 & -2.235 & 0.122 & -18.285 & $<0.001^{* * *}$ & -1.915 & 0.360 & -5.312 & $<0.001^{* * *}$ \\
\hline PROP_ONA_2 & -1.575 & 0.086 & -18.283 & $<0.001^{* * *}$ & -2.490 & 0.293 & -8.500 & $<0.001^{* * *}$ \\
\hline PROP_ONA_4 & 1.128 & 0.067 & 16.900 & $<0.001^{* * *}$ & 0.214 & 0.137 & 1.570 & 0.116 \\
\hline PROP_ONA_5 & 3.045 & 0.070 & 43.734 & $<0.001^{* * *}$ & 2.556 & 0.138 & 18.555 & $<0.001^{* * * *}$ \\
\hline Q_CAR_2 & & & & & 0.644 & 0.126 & 5.108 & $<0.001^{* * *}$ \\
\hline Q_CAR_4 & -0.284 & 0.049 & -5.841 & $<0.001^{* * *}$ & 0.255 & 0.105 & 2.427 & 0.015 * \\
\hline Q_CAR_5 & & & & & 1.095 & 0.249 & 4.398 & $<0.001 * * *$ \\
\hline Q_CIRC_1 & & & & & 0.592 & 0.111 & 5.320 & $<0.001^{* * *}$ \\
\hline Q_CIRC_2 & -0.100 & 0.049 & -2.039 & $0.041 *$ & & & & \\
\hline Q_PT_1 & & & & & 0.283 & 0.133 & 2.128 & 0.033 * \\
\hline Q_PT_2 & 0.102 & 0.060 & 1.720 & $0.085^{\dagger}$ & & & & \\
\hline
\end{tabular}


Table 4. Cont.

\begin{tabular}{|c|c|c|c|c|c|c|c|c|}
\hline \multirow[b]{2}{*}{ Name } & \multicolumn{4}{|c|}{ Students } & \multicolumn{4}{|c|}{ Employees } \\
\hline & Coeff. & SE & z-Value & $p$-Value & Coeff. & SE & z-Value & $p$-Value \\
\hline Q_PT_4 & -0.135 & 0.057 & -2.371 & 0.018 * & & & & \\
\hline Q_WALK_2 & & & & & 0.278 & 0.138 & 2.008 & 0.044 * \\
\hline Q_WALK_4 & 0.080 & 0.046 & 1.735 & $0.083^{\dagger}$ & 0.363 & 0.102 & 3.544 & $<0.001^{* * *}$ \\
\hline RISK & -0.134 & 0.088 & -1.530 & 0.126 & & & & \\
\hline SAF_CPASS & -0.040 & 0.021 & -1.863 & $0.062^{+}$ & & & & \\
\hline SAF_INDIV & & & & & -0.081 & 0.044 & -1.829 & $0.067^{\dagger}$ \\
\hline SAF_PT & -0.103 & 0.024 & -4.247 & $<0.001^{* * *}$ & -0.174 & 0.047 & -3.705 & $<0.001^{* * *}$ \\
\hline SAF_SH & 0.033 & 0.023 & 1.464 & 0.143 & & & & \\
\hline SAT_1 & & & & & -0.536 & 0.363 & -1.480 & 0.139 \\
\hline SAT_2 & 0.125 & 0.065 & 1.931 & $0.053^{\dagger}$ & 0.413 & 0.207 & 1.992 & $0.046^{*}$ \\
\hline SAT_4 & 0.122 & 0.053 & 2.316 & 0.021 * & 0.434 & 0.167 & 2.590 & $0.009^{* *}$ \\
\hline SAT_5 & & & & & 0.247 & 0.177 & 1.392 & 0.163 \\
\hline SP_BP_A & -1.057 & 0.149 & -7.072 & $<0.001^{* * *}$ & -0.700 & 0.276 & -2.536 & 0.012 * \\
\hline SP_BP_B & -1.006 & 0.097 & -10.419 & $<0.001^{* * *}$ & -0.805 & 0.198 & -4.061 & $<0.001^{* * *}$ \\
\hline SP_BP_C & -1.043 & 0.099 & -10.497 & $<0.001^{* * *}$ & -0.836 & 0.207 & -4.047 & $<0.001^{* * *}$ \\
\hline SP_BP_D & -1.165 & 0.162 & -7.213 & $<0.001^{* * *}$ & -0.626 & 0.293 & -2.136 & $0.032 *$ \\
\hline SP_BS_B & -0.649 & 0.348 & -1.864 & $0.062^{+}$ & & & & \\
\hline SP_BS_D & & & & & 1.420 & 0.797 & 1.782 & $0.074^{\dagger}$ \\
\hline SP_COST & 0.023 & 0.008 & 2.971 & $0.003^{* * *}$ & 0.229 & 0.059 & 3.907 & $<0.001^{* * *}$ \\
\hline SP_CP_A & & & & & 0.655 & 0.499 & 1.311 & 0.190 \\
\hline SP_CP_B & & & & & 1.200 & 0.262 & 4.575 & $<0.001^{* * *}$ \\
\hline SP_CP_C & -0.602 & 0.140 & -4.295 & $<0.001^{* * *}$ & 0.910 & 0.363 & 2.507 & 0.012 * \\
\hline SP_CP_D & & & & & 0.481 & 0.325 & 1.479 & 0.139 \\
\hline SP_IVT & 0.006 & 0.001 & 6.666 & $<0.001^{* * *}$ & 0.012 & 0.003 & 4.499 & $<0.001^{* * *}$ \\
\hline SP_MO_A & -0.849 & 0.493 & -1.722 & $0.085^{\dagger}$ & & & & \\
\hline SP_MO_B & -0.621 & 0.402 & -1.546 & 0.122 & & & & \\
\hline SP_MO_C & -0.643 & 0.354 & -1.814 & $0.069^{\dagger}$ & & & & \\
\hline SP_MO_D & & & & & -1.317 & 1.056 & -1.247 & 0.212 \\
\hline SP_PT_A & 0.324 & 0.136 & 2.378 & 0.017 * & 0.603 & 0.373 & 1.616 & 0.106 \\
\hline SP_PT_C & & & & & 0.553 & 0.237 & 2.328 & $0.020^{*}$ \\
\hline SP_PT_D & -0.234 & 0.115 & -2.029 & 0.042 * & & & & \\
\hline SP_WALK & & & & & 0.034 & 0.011 & 2.947 & $0.003^{* *}$ \\
\hline SUB_BUS_U & & & & & 0.703 & 0.222 & 3.172 & $0.002^{* *}$ \\
\hline \multicolumn{9}{|c|}{ Significance codes: ${ }^{* * *} p$-value $<0.001 ;{ }^{* *} p$-value $<0.01 ;{ }^{*} p$-value $<0.05 ;+p$-value $<0.10$} \\
\hline \multicolumn{9}{|c|}{ Statistics } \\
\hline N. of observations & & & 19,188 & & & & 077 & \\
\hline Null deviance & & & 26,086 & & & & 515 & \\
\hline Residual deviance & & & 13,170 & & & & 376 & \\
\hline AIC (Akaike criterion) & & & 13,270 & & & & 507 & \\
\hline Null log likelihood & & & $13,042.03$ & & & & 757.51 & \\
\hline Final log likelihood & & & 6585.12 & & & & 87.87 & \\
\hline Cragg and Uhler's pseudo $\mathrm{R}^{2}$ & & & 0.66 & & & & .55 & \\
\hline McFadden pseudo $\mathrm{R}^{2}$ & & & 0.50 & & & & .39 & \\
\hline Maximum likelihood pseudo $\mathrm{R}^{2}$ & & & 0.49 & & & & .41 & \\
\hline
\end{tabular}

Concerning students, Table 4 shows that age (AGE) was found to be significant and positive, highlighting that older students tend to stay at home, probably since they have already experienced university learning and they have more lessons to attend than younger individuals, therefore they are more willing to adopt online learning to spare travel time. Moreover, males exhibited less probability to cancel trips compared with females (GENDER_M). As regards variables related to the pre-COVID-19 period, travel habits before the COVID-19 outbreak were found to be significant in trip cancellation; in particular, a frequent use of travel modes associated with typical urban trip lengths increased travel propensity (F_WALK and F_BUS_U), on the contrary the use of trains 
had the opposite effect (F_TRAIN); this might suggest that people who often carried out long trips in the past were more likely to stay at home. The role of sub urban bus was unexpected since P_BUS_S is negative; however, even if students used sub urban bus in the past, they might shift to another mode to perform the school trip in the future. This might be confirmed by observing that the effect of the satisfaction level of past travel modes on trip cancellation was not clear indicating that other variables affect that choice (both SAT_2 and SAT_4 are positive). This aspect might need to be clarified by further analysis. As in previous works, trip frequency before the pandemic played a fundamental role in travel decisions; in particular, students who often went to university were less likely not to perform that trip in the future (FREQ). Concerning general opinions about available travel modes and the transport system, regardless of the COVID-19 pandemic, the quality of public transport service and road infrastructure significantly affected the choice to cancel the trip (Q_PT_2,Q_PT_4 and Q_CAR_4); however, students tended to decide to travel even if the quality of traffic circulation was considered poor (Q_CIRC_2). As regards the "new normal" phase, the propensity towards online learning significantly affected the choice to cancel the trip; specifically, only students satisfied with online activity were willing to stay at home (PROP_ONA). On the other hand, the COVID-19 pandemic was found to influence trip cancellation; indeed, students worried about the current situation (PERC_COV_4) and those who thought that the spread of the virus would not be reduced (FUT_COV_5 and FUT_COV_6) were more likely not to perform the school trip; on the contrary, those who considered a future reduction of SARS-CoV-2 diffusion were more willing to travel (FUT_COV_2). Moreover, both factors SAF_CPASS and SAF_TP were found to be significant and negative, suggesting that risk perception of travelling with other passengers and on public transport means might affect the choice to cancel the trip. In addition, this decision in "new normal" conditions was mainly affected by the available travel modes and risk mitigation measures on means. In particular, private car use, the potential future use of bikes (SP_BP_A, SP_BP_B, SP_BP_C and SP_BP_D) and shared scooters (SP_MO_A and SP_MO_C) reduces the probability of staying at home; nevertheless, COVID-19 countermeasures had a significant impact on trip cancellation, as regards first public transport (since students were willing to use it only if measures were enforced) (SP_PT_A), and then bike sharing (SP_BS_B) and car pooling (SP_CP_C). Specifically, this indicates that if specific risk mitigation measures are introduced on public transport vehicles (mandatory face mask usage and the presence of a person designated to enforce safety measures), bike sharing (frequent sanitization of bikes by operators) and car pooling (hand sanitizing gel on each vehicle), the number of educational trips on these modes can be increased. On the other hand, the effect on travel choice of risk mitigation measures in educational settings was secondary, indeed, even students judging some measures as important were willing to stay at home (MEAS_A_4 and MEAS_A_5); however, some interventions might be effective in fostering trips, like free hand sanitizing gel at entry points (MEAS_D_5).

Collinearity analysis highlighted no correlation among exogenous variables; in addition, values of variable inflation factors were lower than 4 , suggesting no multicollinearity [74].

Focusing on employees, Table 4 reports that age (AGE) had a negative impact on the probability of cancelling commuting trips, probably since older employees had got used to performing working or teaching activities in university and were less willing to change their habits. This is confirmed by the negative coefficient of FREQ, highlighting that the frequency of commuting travel positively affected the choice to make it in the future. Household income increased the probability to stay at home (INCOME) since wealthier people are more likely to own private working rooms and good computer equipment. Moreover, even if the availability of cars in the household rose, the probability of carrying out the trip was reduced (HH_CAR/HH_LIC); in addition, even employees reporting a high quality of road infrastructure were willing to stay at home (Q_CAR_4 and Q_CAR_5); these two observations suggest that, beyond private car usage, other factors might prompt 
this decision. Observing $\mathrm{P}_{-}{ }^{*}$ variables can be useful to identify potential decreasing adoption of travel modes; in particular, pre-COVID-19 trips in private cars with other passengers (P_PASS), sub urban bus (P_BUS_S), bike use (P_BIKE) and walking (P_WALK) could be reduced in the future. Both positive (SAT_4) and negative levels of satisfaction for past travel modes (SAT_2) equally increased the likelihood of cancelling the trip, indicating a potential role of other variables. Indeed, the propensity towards remote working had a positive impact on the choice not to commute (PROP_ONA). As regards COVID-19 effects on travel decisions, people who thought that SARS-CoV-2 would be widespread in the future were more likely to stay at home (FUT_COV_4 and FUT_COV_5), whereas workers sharing the opposite opinion were more likely to travel (FUT_COV_2). Furthermore, the perceived level of health risk on travel means was found to be significant, in particular for individual (SAF_INDIV) and public transport means (SAF_PT). Considering CHOICE_* variables one can note that the use of bikes increased the choice to commute, if compared to private car use. On the other hand, risk-mitigation measures on public transport, bike sharing and car pooling did not reduce the probability of staying at home. Moreover, only a few interventions in working areas at university fostered the decision to make the trip, i.e., mandatory face mask usage in working/studying environments in university buildings (MEAS_B_4 and MEAS_B_5) and body heat checks at entry points in university buildings (MEAS_E_4 and MEAS_E_5).

Results from collinearity analysis indicated no correlation among independent factors; moreover, variance inflation factors below 4 were obtained, suggesting no multicollinearity effects [74].

\section{Discussion}

Results of binary logistic regression models highlighted variables affecting the choice not to perform systematic trips of students and employees. In particular, the analysis pointed out that the two samples have both differences and similarities.

Concerning dissimilarities, age showed an opposite effect on trip cancellation; specifically, younger students tend to go to university, whereas younger employees tend to stay at home $[4,7,23,45]$. Income was found to have a positive effect on the probability not to carry out the trip $[4,45,46]$, but only for employees. Gender has an impact only for students, with males more willing to travel rather females $[10,12,29,46,65]$. Moreover, as a consequence of the choice to stay at home, the developed model predicts that employees might reduce their commuting trips using sub urban bus, bikes and walking.

On the other hand, trip frequency before the COVID-19 outbreak has a negative impact on the choice to cancel the journey $[23,29,46]$ for both students and workers. As regards the effects of COVID-19 on educational and working trips, health risk perception plays a fundamental role in trip cancellation decisions [19], in particular for public transport modes $[24,65]$. This points out that a proper information campaign on the use of such means can significantly impact future travel demand [4,7,31]. Moreover, people's opinion about the potential future diffusion of COVID-19 was found to be a significant variable for the choice to cancel a trip in both samples, highlighting the great impact of how news about the spread of the virus is communicated. Furthermore, alternative modes available in "new normal" conditions and related risk-mitigation measures were observed to influence future travel demand. Specifically, for both students and employees, the stated choice of future bike usage increased the probability of making the trip, rather than private car choice. Concerning public transport, if no COVID-19 countermeasures were applied, potential transit users would be likely to stay at home; on the other hand, students might decide to perform the trip on public transport if the presence of a designated person enforcing safety measures was guaranteed in each vehicle, whereas employees might not travel even if measures were implemented. In addition, unlike employees, specific countermeasures were found to be effective to promote students' travel decisions on the corresponding means: frequent sanitization of bikes by operators, for bike sharing, and available hand sanitizing gel on each vehicle for car pooling and scooter sharing. Furthermore, results 
pointed out potential new trips on scooter sharing, which students might adopt even if no measures were enforced. Moreover, the analysis indicated that only some risk-mitigation interventions in work and study settings could reduce the probability of not performing the trip, i.e., free hand sanitizing gel at entry points for students, and mandatory face mask usage and body heat checks for employees.

\section{Conclusions}

With reference to the diffusion of the COVID-19 pandemic, in this paper, factor analysis and binary logistic regression models were developed to predict factors affecting the decision to carry out systematic trips (educational and working trips) in "new normal" conditions, when people can decide whether to travel or stay at home performing online mandatory activities. These models were calibrated by using data from a mobility survey administered to students and employees in the University of Padova (Italy), where respondents were asked to answer both revealed-preferences and stated-preferences questions. The former includes detailed travel habits and characteristics of mandatory trips before, during and after the COVID-19 lockdown, risk perception on travel modes, attitudes towards online activities and opinions about countermeasures against SARS-CoV-2 diffusion in university buildings; whereas the latter were based on a real educational/working trip with realistic trip attributes on traditional and potential new mobility services, considering also different COVID-19 risk mitigation measures on means.

Unlike previous work, the outcomes of models highlighted that factors affecting travel decisions in a "new normal" phase are different between students and employees, thus supporting the reason for the specific analysis on the former carried out in this paper for the first time. Moreover, attitudes towards online activities and risk perception of COVID-19 diffusion on different travel modes play an important role on choice, thus underlying the importance of proper information campaigns. In addition, available travel alternatives and risk mitigation measures on vehicles were found to be significant, indicating that they should be considered in travel demand prediction. Lastly, the promotion of the adoption of bikes can be an effective way to encourage future sustainable mobility, as well as the fostering of bike sharing, car pooling and micro mobility among students. On the other hand, countermeasures on studying/working places resulted in only a slight effect on travel decisions.

Results are helpful for policy makers and local authorities in managing a fundamental part of travel demand, which should be guaranteed with a proper health safety level. In addition, trips on different travel modes can be quantified and addressed towards sustainable mobility habits, thus contributing to the generation of a resilient transport system and maintenance of the few nonnegative effects on society highlighted in several cities during the COVID-19 pandemic, such as reduction of congestion and environmental pollution.

Author Contributions: Conceptualization, R.R., M.G. and R.C.; methodology, R.R., M.G. and R.C.; software, R.C.; formal analysis, R.C.; resources, R.R. and M.G.; writing—original draft preparation, R.C.; writing-review and editing, R.R. and M.G.; visualization, R.C.: supervision, R.R and M.G. All authors have read and agreed to the published version of the manuscript.

Funding: This research received no external funding.

Institutional Review Board Statement: Not applicable.

Informed Consent Statement: Not applicable.

Data Availability Statement: The data presented in this study are available on request from the corresponding author.

Conflicts of Interest: The authors declare no conflict of interest. 


\section{References}

1. Molloy, J.; Schatzmann, T.; Schoeman, B.; Tchervenkov, C.; Hintermann, B.; Axhausen, K.W. Observed impacts of the COVID-19 first wave on travel behaviour in Switzerland based on a large GPS panel. Transp. Policy 2021, 104, 43-51. [CrossRef]

2. Guan, W.; Ni, Z.; Hu, Y.; Liang, W.; Ou, C.; He, J.; Liu, L.; Shan, H.; Lei, C.; Hui, D.S.C.; et al. Clinical Characteristics of Coronavirus Disease 2019 in China. N. Engl. J. Med. 2020, 382, 1708-1720. [CrossRef]

3. World Health Organization. Virtual Press Conference on COVID-19; 11 March 2020; World Health Organization: Geneva, Switzerland, 2020.

4. Beck, M.J.; Hensher, D.A. Insights into the impact of COVID-19 on household travel and activities in Australia-The early days under restrictions. Transp. Policy 2020, 96, 76-93. [CrossRef] [PubMed]

5. World Health Organization. Coronavirus Disease 2019 (COVID-19). Situation Report-71; World Health Organization: Geneva, Switzerland, 2020.

6. World Health Organization. COVID-19 Weekly Epidemiological Update; World Health Organization: Geneva, Switzerland, 2021.

7. Shibayama, T.; Sandholzer, F.; Laa, B.; Brezina, T. Impact of COVID-19 lockdown on commuting: A multi-country perspective. Eur. J. Transp. Infrastruct. Res. 2021, 21, 70-93. [CrossRef]

8. Bin, E.; Andruetto, C.; Susilo, Y.; Pernestål, A. The trade-off behaviours between virtual and physical activities during the first wave of the COVID-19 pandemic period. Eur. Transp. Res. Rev. 2021, 13. [CrossRef]

9. de Haas, M.; Faber, R.; Hamersma, M. How COVID-19 and the Dutch 'intelligent lockdown' change activities, work and travel behaviour: Evidence from longitudinal data in the Netherlands. Transp. Res. Interdiscip. Perspect. 2020, 6, 100150. [CrossRef]

10. Nguyen, M.H. Factors Influencing Home-Based Telework in Hanoi (Vietnam) during and after the COVID-19 Era. Transportation 2021, 1-32. [CrossRef]

11. Moslem, S.; Campisi, T.; Szmelter-Jarosz, A.; Duleba, S.; Nahiduzzaman, K.M.; Tesoriere, G. Best-worst method for modelling mobility choice after COVID-19: Evidence from Italy. Sustainability 2020, 12, 6824. [CrossRef]

12. Politis, I.; Georgiadis, G.; Papadopoulos, E.; Fyrogenis, I.; Nikolaidou, A.; Kopsacheilis, A.; Sdoukopoulos, A.; Verani, E. COVID19 lockdown measures and travel behavior: The case of Thessaloniki, Greece. Transp. Res. Interdiscip. Perspect. 2021, $10,100345$. [CrossRef]

13. Awad-Núñez, S.; Julio, R.; Gomez, J.; Moya-Gómez, B.; González, J.S. Post-COVID-19 travel behaviour patterns: Impact on the willingness to pay of users of public transport and shared mobility services in Spain. Eur. Transp. Res. Rev. 2021, 13, 20. [CrossRef]

14. Anke, J.; Francke, A.; Schaefer, L.M.; Petzoldt, T. Impact of SARS-CoV-2 on the mobility behaviour in Germany. Eur. Transp. Res. Rev. 2021, 13, 10. [CrossRef]

15. Aristovnik, A.; Keržič, D.; Ravšelj, D.; Tomaževič, N.; Umek, L. Impacts of the COVID-19 pandemic on life of higher education students: A global perspective. Sustainability 2020, 12, 8438. [CrossRef]

16. Campisi, T.; Basbas, S.; Skoufas, A.; Akgün, N.; Ticali, D.; Tesoriere, G. The impact of COVID-19 pandemic on the resilience of sustainable mobility in sicily. Sustainability 2020, 12, 8829. [CrossRef]

17. Scorrano, M.; Danielis, R. Active mobility in an Italian city: Mode choice determinants and attitudes before and during the COVID-19 emergency. Res. Transp. Econ. 2021, 86, 101031. [CrossRef]

18. Ministero della Salute-Istituto Superiore di Sanità. Prevention and Response to COVID-19: Evolution of Strategy and Planning in the Transition Phase for the Autumn-Winter Season, English Version; Ministero della Salute-Istituto Superiore di Sanità: Rome, Italy, 2020.

19. Shamshiripour, A.; Rahimi, E.; Shabanpour, R.; Mohammadian, A. (Kouros) How is COVID-19 reshaping activity-travel behavior? Evidence from a comprehensive survey in Chicago. Transp. Res. Interdiscip. Perspect. 2020, 7, 100216. [CrossRef]

20. Borkowski, P.; Jażdżewska-Gutta, M.; Szmelter-Jarosz, A. Lockdowned: Everyday mobility changes in response to COVID-19. J. Transp. Geogr. 2021, 90, 102906. [CrossRef]

21. Abdullah, M.; Dias, C.; Muley, D.; Shahin, M. Exploring the impacts of COVID-19 on travel behavior and mode preferences. Transp. Res. Interdiscip. Perspect. 2020, 8, 100255. [CrossRef]

22. Beria, P.; Lunkar, V. Presence and mobility of the population during the first wave of COVID-19 outbreak and lockdown in Italy. Sustain. Cities Soc. 2021, 65, 102616. [CrossRef]

23. Pawar, D.S.; Yadav, A.K.; Choudhary, P.; Velaga, N.R. Modelling work- and non-work-based trip patterns during transition to lockdown period of COVID-19 pandemic in India. Travel Behav. Soc. 2021, 24, 46-56. [CrossRef]

24. Barbieri, D.M.; Lou, B.; Passavanti, M.; Hui, C.; Hoff, I.; Lessa, D.A.; Sikka, G.; Chang, K.; Gupta, A.; Fang, K.; et al. Impact of COVID-19 pandemic on mobility in ten countries and associated perceived risk for all transport modes. PLoS ONE 2021, 16, e0245886. [CrossRef] [PubMed]

25. Politis, I.; Georgiadis, G.; Nikolaidou, A.; Kopsacheilis, A.; Fyrogenis, I.; Sdoukopoulos, A.; Verani, E.; Papadopoulos, E. Mapping travel behavior changes during the COVID-19 lock-down: A socioeconomic analysis in Greece. Eur. Transp. Res. Rev. 2021, 13, 21. [CrossRef]

26. Eisenmann, C.; Nobis, C.; Kolarova, V.; Lenz, B.; Winkler, C. Transport mode use during the COVID-19 lockdown period in Germany: The car became more important, public transport lost ground. Transp. Policy 2021, 103, 60-67. [CrossRef]

27. Pepe, E.; Bajardi, P.; Gauvin, L.; Privitera, F.; Lake, B.; Cattuto, C.; Tizzoni, M. COVID-19 outbreak response: A first assessment of mobility changes in Italy following national lockdown. MedRxiv 2020, 1-16. [CrossRef]

28. ISFORT. La Mobilità Degli Italiani Dopo il Confinamento; ISFORT: Rome, Italy, 2020. 
29. Hiselius, L.W.; Arnfalk, P. When the impossible becomes possible: COVID-19's impact on work and travel patterns in Swedish public agencies. Eur. Transp. Res. Rev. 2021, 13, 17. [CrossRef]

30. Gkiotsalitis, K.; Cats, O. Public transport planning adaption under the COVID-19 pandemic crisis: Literature review of research needs and directions. Transp. Rev. 2020, 41, 374-392. [CrossRef]

31. Tirachini, A.; Cats, O. COVID-19 and public transportation: Current assessment, prospects, and research needs. J. Public Transp. 2020, 22, 1-21. [CrossRef]

32. Sharifi, A.; Khavarian-Garmsir, A.R. The COVID-19 pandemic: Impacts on cities and major lessons for urban planning, design, and management. Sci. Total Environ. 2020, 749, 142391. [CrossRef]

33. Dantas, G.; Siciliano, B.; França, B.B.; da Silva, C.M.; Arbilla, G. The impact of COVID-19 partial lockdown on the air quality of the city of Rio de Janeiro, Brazil. Sci. Total Environ. 2020, 729, 139085. [CrossRef] [PubMed]

34. Muhammad, S.; Long, X.; Salman, M. COVID-19 pandemic and environmental pollution: A blessing in disguise ? Sci. Total Environ. 2020, 728, 138820. [CrossRef]

35. Connerton, P.; de Assunção, J.V.; de Miranda, R.M.; Slovic, A.D.; Pérez-Martínez, P.J.; Ribeiro, H. Air quality during COVID-19 in four megacities: Lessons and challenges for public health. Int. J. Environ. Res. Public Health 2020, 17, 5067. [CrossRef] [PubMed]

36. Baldasano, J.M. COVID-19 lockdown effects on air quality by $\mathrm{NO}_{2}$ in the cities of Barcelona and Madrid (Spain). Sci. Total Environ. 2020, 741. [CrossRef]

37. Marinello, S.; Lolli, F.; Gamberini, R. The impact of the COVID-19 emergency on local vehicular traffic and its consequences for the environment: The case of the city of Reggio Emilia (Italy). Sustainability 2021, 13, 118. [CrossRef]

38. Rossi, R.; Ceccato, R.; Gastaldi, M. Effect of road traffic on air pollution. Experimental evidence from COVID-19 lockdown. Sustainability 2020, 12, 8984. [CrossRef]

39. Saladié, Ò.; Bustamante, E.; Gutiérrez, A. COVID-19 lockdown and reduction of traffic accidents in Tarragona province, Spain. Transp. Res. Interdiscip. Perspect. 2020, 8. [CrossRef]

40. Gupta, M.; Pawar, N.M.; Velaga, N.R. Impact of lockdown and change in mobility patterns on road fatalities during COVID-19 pandemic. Transp. Lett. 2021, 13, 447-460. [CrossRef]

41. Harantová, V.; Hájnik, A.; Kalašová, A. Comparison of the flow rate and speed of vehicles on a representative road section before and after the implementation of measures in connection with COVID-19. Sustainability 2020, 12, 7216. [CrossRef]

42. Du, J.; Rakha, H.A.; Filali, F.; Eldardiry, H. COVID-19 pandemic impacts on traffic system delay, fuel consumption and emissions. Int. J. Transp. Sci. Technol. 2021, 10, 184-196. [CrossRef]

43. Basu, B.; Murphy, E.; Molter, A.; Sarkar Basu, A.; Sannigrahi, S.; Belmonte, M.; Pilla, F. Investigating changes in noise pollution due to the COVID-19 lockdown: The case of Dublin, Ireland. Sustain. Cities Soc. 2021, 65, 102597. [CrossRef]

44. Pawar, D.S.; Yadav, A.K.; Akolekar, N.; Velaga, N.R. Impact of physical distancing due to novel coronavirus (SARS-CoV-2) on daily travel for work during transition to lockdown. Transp. Res. Interdiscip. Perspect. 2020, 7, 100203. [CrossRef]

45. Fatmi, M.R.; Thirkell, C.; Hossain, M.S. COVID-19 and Travel: How Our Out-of-home Travel Activity, In-home Activity, and Long-Distance Travel Have Changed. Transp. Res. Interdiscip. Perspect. 2021, 10, 100350. [CrossRef]

46. Irawan, M.Z.; Belgiawan, P.F.; Joewono, T.B.; Bastarianto, F.F.; Rizki, M.; Ilahi, A. Exploring activity-travel behavior changes during the beginning of COVID-19 pandemic in Indonesia. Transportation 2021. [CrossRef] [PubMed]

47. Ozbilen, B.; Slagle, K.M.; Akar, G. Perceived risk of infection while traveling during the COVID-19 pandemic: Insights from Columbus, OH. Transp. Res. Interdiscip. Perspect. 2021, 10, 100326. [CrossRef] [PubMed]

48. United Nations. Recommendations for Green and Healthy Sustainable Transport_-"Building Forward Better"; United Nations: Geneva, Switzerland, 2021.

49. Lozzi, G.; Rodrigues, M.; Marcucci, E.; Teoh, T.; Gatta, V.; Pacelli, V. Research for TRAN Committee—COVID-19 and Urban Mobility: Impacts and Perspectives; European Parliament, Policy Department for Structural and Cohesion Policies: Brussels, Belgium, 2020.

50. Mouratidis, K.; Peters, S.; van Wee, B. Transportation technologies, sharing economy, and teleactivities: Implications for built environment and travel. Transp. Res. Part D Transp. Environ. 2021, 92, 102716. [CrossRef]

51. Hensher, D.A.; Beck, M.J.; Wei, E. Working from home and its implications for strategic transport modelling based on the early days of the COVID-19 pandemic. Transp. Res. Part A Policy Pract. 2021, 148, 64-78. [CrossRef]

52. Beck, M.J.; Hensher, D.A.; Wei, E. Slowly coming out of COVID-19 restrictions in Australia: Implications for working from home and commuting trips by car and public transport. J. Transp. Geogr. 2020, 88. [CrossRef] [PubMed]

53. Mok, K.H.; Xiong, W.; Ke, G.; Cheung, J.O.W. Impact of COVID-19 pandemic on international higher education and student mobility: Student perspectives from mainland China and Hong Kong. Int. J. Educ. Res. 2021, 105, 101718. [CrossRef]

54. Drašler, V.; Bertoncelj, J.; Korošec, M.; Žontar, T.P.; Ulrih, N.P.; Cigić, B. Difference in the attitude of students and employees of the university of ljubljana towards work from home and online education: Lessons from COVID-19 pandemic. Sustainability 2021, 13, 5118. [CrossRef]

55. Cicha, K.; Rizun, M.; Rutecka, P.; Strzelecki, A. COVID-19 and higher education: First-year students' expectations toward distance learning. Sustainability 2021, 13, 1889. [CrossRef]

56. Garikapati, V.M.; You, D.; Pendyala, R.M.; Patel, T.; Kottommannil, J.; Sussman, A. Design, development, and implementation of a university travel demand modeling framework. Transp. Res. Rec. 2016, 2563, 105-113. [CrossRef]

57. Konečný, V.; Brídziková, M.; Senko, Š. Impact of COVID-19 and anti-pandemic measures on the sustainability of demand in suburban bus transport. The case of the slovak republic. Sustainability 2021, 13, 4967. [CrossRef] 
58. Wang, X.; Khattak, A.J.; Son, S. What can be learned from analyzing university student travel demand? Transp. Res. Rec. 2012, 2322, 129-137. [CrossRef]

59. Khattak, A.; Wang, X.; Son, S.; Agnello, P. Travel by university students in Virginia: Is this travel different from travel by the general population? Transp. Res. Rec. 2011, 2255, 137-145. [CrossRef]

60. Kuhfeld, M.; Soland, J.; Tarasawa, B.; Johnson, A.; Ruzek, E.; Liu, J. Projecting the Potential Impact of COVID-19 School Closures on Academic Achievement. Educ. Res. 2020, 49, 549-565. [CrossRef]

61. Van Nguyen, D.; Pham, G.H.; Nguyen, D.N. Impact of the COVID-19 pandemic on perceptions and behaviors of university students in Vietnam. Data Brief 2020,31, 105880. [CrossRef]

62. Wu, S.J.; Chang, D.F.; Sun, F.R. Exploring college student's perspectives on global mobility during the COVID-19 pandemic recovery. Educ. Sci. 2020, 10, 218. [CrossRef]

63. Bhaduri, E.; Manoj, B.S.; Wadud, Z.; Goswami, A.K.; Choudhury, C.F. Modelling the effects of COVID-19 on travel mode choice behaviour in India. Transp. Res. Interdiscip. Perspect. 2020, 8, 100273. [CrossRef]

64. Irawan, M.Z.; Rizki, M.; Joewono, T.B.; Belgiawan, P.F. Exploring the intention of out-of-home activities participation during new normal conditions in Indonesian cities. Transp. Res. Interdiscip. Perspect. 2020, 8, 100237. [CrossRef]

65. Parady, G.; Taniguchi, A.; Takami, K. Travel behavior changes during the COVID-19 pandemic in Japan: Analyzing the effects of risk perception and social influence on going-out self-restriction. Transp. Res. Interdiscip. Perspect. 2020, 7, 100181. [CrossRef]

66. Ortuzar, D.; Willumsen, L.G. Modelling Transport, 4th ed.; John Wiley \& Sons: New York, NY, USA, 2011; ISBN 9780470760390.

67. Hensher, D.A.; Rose, J.M.; Greene, W.H. Applied Choice Analysis: A Primer; Cambridge University Press: Cambridge, UK, 2005.

68. Heilig, M.; Mallig, N.; Hilgert, T.; Kagerbauer, M.; Vortisch, P. Large-Scale Application of a Combined Destination and Mode Choice Model Estimated with Mixed Stated and Revealed Preference Data. Transp. Res. Rec. J. Transp. Res. Board 2017, 2669, 31-40. [CrossRef]

69. Diana, M. From mode choice to modal diversion: A new behavioural paradigm and an application to the study of the demand for innovative transport services. Technol. Forecast. Soc. Chang. 2010, 77, 429-441. [CrossRef]

70. Train, K.; Wilson, W.W. Estimation on stated-preference experiments constructed from revealed-preference choices. Transp. Res. Part B Methodol. 2008, 42, 191-203. [CrossRef]

71. Wheeler, B. R Package AlgDesign. R Proj. Stat. Comput. 2019, 1.2.0, 1-25.

72. Yang, L.; Liu, J.; Lu, Y.; Ao, Y.; Guo, Y.; Huang, W.; Zhao, R.; Wang, R. Global and local associations between urban greenery and travel propensity of older adults in Hong Kong. Sustain. Cities Soc. 2020, 63. [CrossRef]

73. Wong, R.C.P.; Szeto, W.Y.; Yang, L.; Li, Y.C.; Wong, S.C. Public transport policy measures for improving elderly mobility. Transp. Policy 2018, 63, 73-79. [CrossRef]

74. Hair, J.F.J.; Black, W.C.; Babin, B.J.; Anderson, R.E. Multivariate Data Analysis, 8th ed.; Cengage Learning EMEA, Ed.; Annabel Ainscow: Andover, UK, 2018; ISBN 978-1-4737-5654-0.

75. R Core Team. R: A Language and Environment for Statistical Computing; R Core Team: Vienna, Austria, 2020.

76. ISFORT. $17^{\circ}$ Rapporto Sulla Mobilità Degli Italiani, Tra Gestione del Presente e Strategie per il Futuro; ISFORT: Rome, Italy, 2020.

77. DiStefano, C.; Zhu, M.; Mîndrilă, D. Understanding and using factor scores: Considerations for the applied researcher. Pract. Assess. Res. Eval. 2009, 14, 20. 